\title{
"Pedaços de carne crua e ensanguentada": uma análise de Casa de Pensão e Mistério da Tijuca de Aluísio Azevedo
}

Ana Gomes Porto

Ao comentar a obra de Aluísio Azevedo em 1888, Araripe Junior sugeria que o escritor, depois da publicação d'O Mulato, “andou a satisfazer a avidez dos leitores de rodapé, escrevendo as Memórias de um Condenado e Os Mistérios da Tijuca”. Para o crítico, essas obras não apresentariam nenhuma característica estética digna de nota, comparando-se aos "pedaços de carne crua e ensanguentada" que os domadores atiram às feras para assanhá-las. No caso, a "fera" seria "o público" e Aluísio Azevedo “o domador”. O aparecimento de Casa de Pensão, entretanto, traria uma mudança, para Araripe Junior, na atitude do escritor. Segundo ele, dentre as suas obras, era essa "a que mais cabalmente afirmava a vis naturalista e descritiva", pois “todos os talentos denunciados n'O Mulato aparecem aí no estado adulto, senão em quase completa maturidade” (ARARIPE JUNIOR, 1960, pp.83-4). Além de ressaltar uma discrepância entre as produções do autor, o crítico chamava atenção para o fato de que as qualidades de "domador" de Aluísio Azevedo eram exacerbadas notadamente nos romances que o crítico considerava "inferiores".

Um século mais tarde, Jean-Yves Mérian afirmaria não ser possível dividir a obra de Aluísio Azevedo "em duas categorias (romances bons e romances ruins)" (MÉRIAN, 1988, p.469), já que o caráter híbrido seria uma marca da sua produção, tendo como função intrínseca inserir pequenas doses do romance moderno em meio a obras que poderiam se adequar ao estilo melodramático francês. Obras como Mistério da Tijuca e Memórias de um Condenado seriam, portanto, híbridas, já que apresentam recorrências típicas do folhetim, como a divisão maniqueísta, um exagero na representação dos personagens (quase caricaturas) e a oposição típica vilão/herói. Mérian denomina essas obras "romances-folhetim" e conclui que, apesar do caráter híbrido (afirmado pelo próprio escritor) e verificável pela análise e comparação das obras, "as passagens naturalistas não mudam nada de importante na estética de cada romance-folhetim considerado em seu conjunto" (MÉRIAN, 1988, p.492).

Este artigo parte da análise das relações entre Mistério da Tijuca e Casa de Pensão. A leitura aqui presente está baseada no contexto de produção dessas obras. Esta estratégia revela novos significados no que concerne ao caráter de cada um desses livros e indicará que ambos possuem características comuns, que os aproximam mais do que os distanciam e que, independentemente da inserção nas categorias "romances bons" ou "romances ruins", ambos se apresentam como consequência de um mesmo tipo de produção literária.

\section{Questão Capistrano e Casa de Pensão}

A publicação de Casa de Pensão teve início em 5 de março de 1883 nos folhetins da Folha Nova e continuou até o capítulo XII, no dia 22 de maio de 1883. Os outros 
capítulos foram publicados sob a forma de fascículos avulsos. ${ }^{2}$ Em 1884 surgiram três edições ${ }^{3}$ em livro, indicando o sucesso da obra entre o público: a primeira pela Faro \& Lino, a segunda pela Tipografia Militar de Santos e Cia. e a terceira, denominada de "edição popular", pela Faro \& Lino novamente. Além de tantas edições em apenas um ano, a existência de uma edição "popular" ressalta o sucesso que o romance fazia já naquele momento de publicação. ${ }^{4}$

O enredo de Casa de Pensão se constrói em torno de Amâncio, jovem maranhense de família rica, que se muda para a Corte com a intenção de estudar medicina. Entretanto, Amâncio ambicionava, sobretudo, o título de doutor. Além disso, tinha o objetivo de morar na Corte: 'Não se trata aqui de fazer um 'médico', trata-se de fazer um 'doutor', seja ele do que bem quiser! Não se trata de ganhar uma 'profissão', trata-se de obter um "título"' (AZEVEDO, 1957, p.43). Como o autor insiste em mostrar, Amâncio não era exatamente um personagem de muitas virtudes:

Há muito tempo ardia de impaciência por tal viagem [ao Rio de Janeiro]; pensara nisso todos os dias; fizera cálculos, imaginara futuras felicidades. Queria teatros bufos, ceias ruidosas ao lado de francesas, passeios fora de horas, a carro, pelos arrabaldes. Seu espírito, excessivamente romântico, como o de todo maranhense nessas condições, pedia uma grande cidade, velha, cheia de ruas tenebrosas, cheia de mistérios, de hotéis, de casas de jogo, de lugares suspeitos e de mulheres caprichosas; fidalgas encantadoras e libertinas, capazes de tudo, por um momento de gozo. E Amâncio sentia necessidade de dar começo àquela existência que encontrara nas páginas de mil romances. Todo ele reclamava amores perigosos, segredos de alcova e loucuras de paixão.

Entretanto, o seu tipo franzino, meio imberbe, meio ingênuo, dizia justamente o contrário. Ninguém, contemplando aquele insignificante rosto moreno, um tanto chupado, aqueles pômulos salientes, aqueles olhos negros, de uma vivacidade quase infantil, aquela boca estreita, guarnecida de bons dentes, claros e alinhados, ninguém acreditaria que ali estivesse um sonhador, um sensual, um louco. (AZEVEDO, 1957, p.25)

Até o capítulo V, a narrativa se desenvolvia em torno da história de dois personagens: Amâncio e João Coqueiro. Aluísio Azevedo apresentava-os de maneira bastante negativa, com uma educação e criação inadequadas. Desta maneira, o leitor conhecia profundamente a infância e a vida de ambos até o momento em que se encontravam no Rio de Janeiro.

Coqueiro se casa com Mme. Brizard, uma francesa bem mais velha, e ambos decidem montar a casa de pensão com o prédio que o mesmo herdara da mãe. Além do casal, passam a viver na casa: a irmã de Coqueiro, Amelinha; os dois filhos de Mme. Brizard - Nini (viúva "histérica, e até meio pateta") e o menino César. Após a detalhada descrição dos dois personagens, a história se desenvolve em torno desta casa: “(....) a casa de pensão de Mme. Brizard (como teimosamente insistiam em lhe chamar a mulher), surgiu ameaçadora, escancarando para a população do Rio de Janeiro a sua boca de monstro" (AZEVEDO, 1957, p.82).

Além dos hóspedes (alguns com mais destaque que outros, por exemplo Lúcia, que tem um pequeno caso com Amâncio), outro grupo de personagens que ocupa um papel importante é a família de Campos, comerciante que inicialmente hospeda Amâncio no Rio de Janeiro: Hortênsia (a esposa) e uma cunhada, D. Carlotinha. Após o encontro com Coqueiro, estudante na Politécnica, Amâncio será seduzido a se mudar para a casa 
de pensão: uma "casa de família", como reitera insistentemente Coqueiro. Desde o início fica patente o interesse do irmão em arrumar um bom casamento para Amelinha. Amâncio terá, portanto, lugar privilegiado na casa de pensão.

Embora o enredo tenha sido elaborado em torno da casa de pensão e seus hóspedes, fica patente quais personagens e relações o autor deseja ressaltar. As insinuações sedutoras de Amelinha sobre Amâncio foram percebidas e incentivadas por Mme. Brizard e Coqueiro. Tratava-se de arranjar logo um bom casamento que garantisse o futuro de todos. Antes do primeiro encontro, Mme. Brizard sugere que ela deveria seduzi-lo: “- Anda lá, minha sonsa, que sabes disso tão bem como eu” (AZEVEDO, 1957, p.86). O jantar em que Amâncio a vê pela primeira vez, e no qual Amelinha representa o principal papel, é marcado pelo encantamento produzido pela moça sobre o estudante:

\footnotetext{
Sem ser verdadeiramente bonita de rosto, era muito simpática e graciosa. Tez macia, de uma palidez fresca de camélia; olhos escuros, um pouco preguiçosos, bem guarnecidos e penetrantes; nariz curto, um nadinha arrebitado; beiços polpudos e viçosos, à maneira de uma fruta que provoca o apetite e dá vontade de morder. Usava o cabelo cofiado sobre a testa, e, quando queria ver ao longe, tinha de costume de apertar as pálpebras e abrir ligeiramente a boca. Amâncio, bebendo aos goles distraídos a sua cerveja nacional, via e sentia tudo isso, e, sem perceber, deixava-se tomar das graças de Amélia. Já lhe preava a carne o mordente calor daquele corpo; já o invadiam o perfume sombroso daquele cabelo e a luz embriagadora daqueles olhos; já o enleava e cingia a doce sensibilidade elástica daquela voz, quebrada, curva, cheia de ondulações, como a cauda crespa de uma cobra.

E, enquanto palavreava com mme. Brizard e com o Coqueiro, percebia que alguma coisa se apoderava dele, que alguma coisa lhe penetrava familiarmente pelos sentidos e aí se derramava e distendia, à semelhança de um polvo que alonga sensualmente os seus langorosos tentáculos. $\mathrm{E}$, sempre dominado pelos encantos da rapariga, alheava-se de tudo que não fosse ela; queria ouvir o que lhe diziam os outros, prestar-lhes atenção, mas o pensamento libertava-se à força e corria a lançar-se aos pés de Amélia, procurando enroscar-se por ela, à feição do tênue vapor do incenso, quando vai subindo e espiralando abraçado a uma coluna de mármore.

Coqueiro fazia não dar por isso e, ao topar com os olhos da mulher, entre eles corria um raio de satisfação, mais ligeiro que um telegrama. (AZEVEDO, 1957, p.94)
}

A relação entre Amélia e Amâncio se tornaria cada vez mais próxima a partir de então. Nos capítulos XI e XII, em que Amâncio está doente, Amélia se transforma em uma dedicada enfermeira. Ao mesmo tempo em que eles se tornavam amantes, a casa de pensão perderia vários hóspedes. Volúvel em relação às mulheres, Amâncio, enquanto se envolvia com Amélia, insinuava-se a Lúcia (outra moradora da casa de pensão) e Hortênsia (mulher de Campos). Porém,passaria a viver cotidianamente com Amélia. A relação ocorre a partir das vontades e desejos de Amélia que, se não os tem realizados, trata o companheiro friamente. Será em decorrência da tensão gerada pela relação - Amélia quer o casamento enquanto Amâncio posterga a decisão - que ocorrerá o indiciamento de Amâncio pelo crime de defloramento da moça. Coqueiro tem participação importante neste desfecho e os últimos capítulos se centram no julgamento de Amâncio, que conquista a assistência e a opinião pública: 
Nada disso teria acontecido, senhor juiz, se me não desafiassem, se me não sobressaltassem os instintos, atirando-a a todo o momento contra mim; se nos não empurrassem um para o outro, com insistência, com tenacidade, deixando-nos a sós horas e horas consecutivas; fazendoa enfermeira ao lado de minha cama, pespegando-a todos os dias, todas as noites, diante de meus olhos, ao alcance de minhas mãos - enfeitada, perfumada, preparada, como uma armadilha, como uma tentação viva e constante!” (AZEVEDO, 1957, p. 280)

No julgamento, Amâncio será absolvido, enquanto Coqueiro e a família se tornam alvo de pilhérias e fofocas. Será em decorrência desta situação que Coqueiro matará Amâncio: "E uma raiva negra, um desespero surdo e profundo entraram-lhe no corpo, que nem um bando de corvos, para lhe comer a carniça do coração. Um profundo desgosto pela vida o levava a pensar na morte (...)" (AZEVEDO, 1957, p. 295).

$\mathrm{Na}$ apresentação do folhetim na Folha Nova, Aluísio Azevedo fazia algumas considerações, especialmente sobre o caráter da obra, que não seria um romance:

Não o qualifico de romance, porque tal nãoé o caráter que lhe tenciono imprimir. Não tenho igualmente a pretensão de fazer dele um livro científico, nem tão pouco realizar uma obra de arte. Apenas me proponho estudar uma das faces mais antipáticas de nossa sociedade - a vida em casa de pensão. Meu único fimé rasgar aos olhos do leitor a parede de uma dessas velhas casas de pensionistas, e expor na sua nudez fria e profundamente comovedora os dramas secretos que aí dentro se consumam, terríveis e obscuros, como a luta dos monstros no fundo do oceano.

Desejo exibir toda a hediondez dessa existência que corrompe nossa sociedade, como uma moléstia secreta e inconfessável corrompe o organismo humano. (Folha Nova, 5 mar. 1883)

Se a casa de pensão era um mal à família e à sociedade, o hóspede desequilibraria a harmonia fundamental e necessária: "o hóspede, por melhor que seja, por mais honesto, por mais respeitador, é sempre um inimigo perigosíssimo que a família tem dentro de si” (Idem). De fato, a casa de pensão ocupa um lugar central na história; porém, o escritor se concentra em alguns personagens. Assim, torna-se relevante trazer ao leitor o passado de Amâncio e Coqueiro, suas histórias anteriores à casa de pensão e que se referem ao período da infância e adolescência. A única personagem que se vincula totalmente à casa de pensão é Amélia, já que foi criada em uma dessas casas.

Com a publicação do romance em 1884, os comentários que se seguem são positivos e referem-se à obra como adepta da "escola moderna":

Filiado à escola moderna, sem contudo cair nos seus exageros peculiares, o livro de que nos ocupamos põe à prova, a par de uma nitidez de linguagem, um raro método descritivo e um profundo talento de observação.

Ele dá-nos a conhecer os seus personagens de um modo tão simples e natural, que, poucas páginas depois da apresentação, identificamo-nos por tal forma com eles, que nos parecem íntimos, de larga convivência e de longo trato.

Por outro lado é conciso e claro na exposição.

O enredo, que ele acompanha de perto como um médico a marcha de uma doença, sem as grandes ficelles do romanticismo e sem cair na vulgaridade, calmo, suave, sereno, caminhando para um fim único, sem desvios, inexoravelmente, com a impassibilidade de um pêndulo. (...) afirmamos que Aluísio, com a publicação de Casa de Pensão, fez jus ao lugar que vagou por morte de Alencar, entre os nossos homens de letras; e a um outro, no primeiro plano, entre os modernos cultores do naturalismo. (O Mequetrefe, 30 jun. 1884) 
Embora elogiada como parte da escola moderna, Casa de Pensão conta, de maneira romanceada, a história de um crime e foi inspirada em um fato de sucesso de público na imprensa e no júri alguns anos antes, como dizia o próprio Aluísio Azevedo no final da apresentação do romance:

\footnotetext{
As consequências de tudo isso são, pois, fáceis de prever. Os fatos reais mostram todos os dias os inconvenientes que resultam desta desordem.

É em torno dessa verdadeira calamidade que se propõe girar o meu novo livro. Ele pretende bater o mal e encher o abismo da casa de pensão com algumas cem páginas de oitavo francês.

Talvez seja até irrisório tentar entupir um abismo com papel, mas em todo o caso a intenção é legítima. (...)

Os males reais só podem ser combatidos pela própria realidade. (Folha Nova, 5 mar. 1883)
}

Esta apresentação do autor, indicando um caminho de leitura, fez parte somente da versão inicial em folhetim. Apesar do interesse em centrar a história na casa de pensão, o que fica mais evidente são as relações que se travam (através da casa de pensão, mas muito em decorrência de comportamentos inadequados nem sempre delimitados por este espaço) entre três personagens - Amâncio, Coqueiro e Amélia - os quais estarão envolvidos no crime que, finalmente, leva à conclusão da história: nos últimos dois capítulos (XX e XXI), Amâncio é acusado e preso. Porém, ao contrário do que imaginava Coqueiro, foi absolvido e contou, ainda, com o apoio dos estudantes em geral.

Entender Casa de Pensão como a análise de um crime torna compreensível o esclarecimento do autor na sua apresentação, que não o qualifica como romance, nem como livro científico, ou obra de arte. $\mathrm{Na}$ verdade, ao "estudar uma das faces mais antipáticas de nossa sociedade - a casa de pensão", há uma visão de determinados lugares propícios aos crimes. O foco se estende para fora do âmbito da casa de pensão e chega à criação de Amâncio. No romance, todo o enredo caminha para a explicação do crime de assassinato de Amâncio, que ocorre quase no final da história, depois de dois longos capítulos sobre o seu julgamento. Coqueiro, no entanto, não o mata em defesa da honra de sua irmã, mas por uma vaidade própria que o tornara foco de pilhérias dos colegas, enquanto Amâncio era transformado em herói.

A referência ao fato verídico é explícita como fonte de inspiração à obra e indica a proximidade de Aluísio Azevedo aos fatos narrados pela imprensa cotidiana. No caso, um crime muito divulgado anos antes, em 1876. Algumas notícias que circularam no final de 1876 no Rio de Janeiro versavam sobre a prisão de um estudante - João Capistrano da Cunha - acusado de ter violentado Júlia Pereira. Capistrano permanece preso durante todo o ano de 1876 e o julgamento ocorreria somente no dia 18 de novembro do mesmo ano. Nos jornais, o réu responde às perguntas e diz que "não praticou violência, que atribui o processo ao ódio que lhe vota a mãe da ofendida; que as contusões que ela apresentou e que constam do corpo de delito foram devidas a um soco que recebeu do irmão quando pretendia dar nele interrogado" (Gazeta de Notícias, 18 nov. 1876). ${ }^{5}$

Segundo informações da Gazeta de Notícias, que detalha o julgamento, "pouco depois do meio dia houve um pequeno sussurro, devido à afluência de pessoas que queriam penetrar à força no recinto". Neste dia o réu é absolvido por unanimidade e "os espectadores prorromperam em vivas e foram acompanhando o Sr. Capistrano", que havia sido posto em liberdade. (Idem) 
Até então, mais um processo do júri resolvido. Porém, no dia 20 de novembro, outra notícia, desta vez com muito mais divulgação, chega aos jornais: Capistrano é assassinado no dia seguinte à sua absolvição pelo irmão de Júlia, Antonio Alexandre Pereira, na Rua da Quitanda, com três tiros. "O acontecimento do dia" na Gazeta de Notícias comenta em detalhes o momento da morte de Capistrano. O corpo é transferido para um sobrado na própria Rua da Quitanda, “o qual durante o dia esteve cheio de visitantes" (Gazeta de Notícias, 20 nov. 1876).

Alexandre Pereira diz que: "praticara esse ato - porque era irmão da moça e havia sofrido muito" (itálico no jornal). Além disso, declarou que "era filho de Alexandre Antonio Pereira, já falecido e de Julia Clara Pereira, ter 23 anos de idade, ser solteiro, estudante da escola Politécnica (...). Declarou que foi ele quem desfechou os tiros sobre João Capistrano da Cunha, não se recordando de quantos tiros disparou em desafronta da honra de sua família que foi ofendida por Capistrano na pessoa de sua irmã (...)" (Idem).

A partir de então as opiniões divergem nos jornais, mas sempre a partir de um mesmo parâmetro: Alexandre Pereira tinha ou não o direito de vingar a honra de sua irmã? ${ }^{6} \mathrm{O}$ desfecho do caso, agora com o julgamento de Alexandre Pereira, em janeiro de 1877, é a sua absolvição do crime de assassinato de Capistrano. Porém, a grande publicidade não se deu durante os julgamentos, mas após o crime de assassinato, decorrência da absolvição de Capistrano do crime de estupro. "A Questão Capistrano" dizia respeito a essas notícias, que colocavam em debate um assunto relevante: a honra feminina.

Certamente o tema era ainda mais delicado se atentarmos para os debates sobre as "casas de tolerância" que ocorriam no mesmo período e traziam artigos no Jornal do Commercio, Gazeta de Notícias e O Globo, justamente nos meses de novembro e dezembro de 1876. A discussão era acerca da regulação das casas ou hotéis de prostituição, com o fim de evitar "os escândalos e os perigos que desenvolve a prostituição pública nesta cidade" (Jornal do Commercio, 6 dez. 1876). Uma das resoluções seria o fechamento das janelas destas casas. A ameaça estaria vinculada à prostituição como um vício "inoculado no nosso organismo social" (Gazeta de Notícias, 2 dez. 1876) e que ameaçava o "decoro público". Paralela a essa "ameaça social” colocava-se a questão da sedução.

Ao retomar o assunto em Casa de Pensão, Aluísio Azevedo não apenas se aproveita de um crime célebre nos anais da justiça brasileira, mas volta a um assunto de grande destaque alguns anos antes. Assim, Casa de Pensão não é somente um dos livros canonizados pela crítica literária, mas a análise desse crime e das suas consequências. E o que deve ser notado é o procedimento que o autor dará para a explicação do crime. Aluísio Azevedo aproveitou-se de uma discussão bastante calorosa e de sucesso na imprensa - honra, sedução, prostituição feminina - como fonte de inspiração para criar o ambiente da casa de pensão, onde há uma degradação dos personagens pelo meio em que convivem (a casa de pensão), o qual é mostrado de forma bastante negativa ao leitor.

A feliz recepção de Casa de Pensão entre os inumeráveis leitores de jornal e folhetim certamente foi decorrência das apropriações feitas pelo escritor de um crime de sucesso na imprensa. Desta forma, dava novos ares a um assunto já quase enterrado - a "Questão Capistrano". Se Casa de Pensão aborda um crime, outro romance de Aluisio Azevedo já havia dado ensejo para história equivalente, também centrada em um crime. Apenas alguns meses antes de Casa de Pensão, Mistério da Tijuca saíra em folhetim pelo mesmo 
jornal - Folha Nova -, entre 22/11/1882 e 18/02/1883, intercalado com o folhetim traduzido O Roubo dos Seis Milhões, publicado entre 24/11/1882 e 24/01/1883.

\title{
Mistério da Tijuca: a crítica e o público.
}

\author{
No Brasil, quem se propuser escrever romances consecutivos, tem fatalmente de lutar \\ com um grande obstáculo - é a disparidade que há entre a massa enorme de leitores e o \\ pequeno grupo de críticos. \\ Os leitores estão em 1820, em pleno romantismo francês, querem o enredo, a ação, o \\ movimento; os críticos porém acompanham a evolução do romance moderno e exigem que \\ o romancista siga as pegadas de Zola e Daudet. \\ Ponson du Terrail é o ideal daqueles; para este Flaubert é o grande mestre. \\ A qual dos dois grupos se deve atender - ao dos leitores ou ao de críticos? \\ Estes decretam, mas aqueles sustentam. Os romances não se escrevem para a crítica, escrevem-se \\ para o público, para o grosso público, que é quem os paga. (Folha Nova, 23 jan. 1883)
}

O capítulo "Onde o autor põe o nariz de fora" fez parte somente da edição em folhetim de Mistério da Tijuca, a mesma publicada em forma de livro pela tipografia do jornal, ${ }^{8}$ seguindo uma prática corriqueira dos jornais que publicavam os seus folhetins em formato de livro assim que saíssem nas folhas. ${ }^{9}$

$\mathrm{Na}$ narrativa há uma infinidade de personagens e planos de ação que aparecem aos olhos do leitor como um emaranhado de histórias que, aparentemente, não se conectam. Segundo o autor, a opção foi proposital, pois "não queríamos apresentar os nossos tipos todos de frente, ao lado uns dos outros, como se nos propuséssemos fotografar no mesmo cartão os estudantes sexto-anistas da escola de medicina". A consequência inevitável foi uma narrativa complexa e enovelada, pois os personagens foram surpreendidos no "lugar e na posição em que os fomos encontrando" (AZEVEDO, s.d., p. 219) .

Um dos personagens é Cecillia, que se casa com Leão Vermelho, oficial da marinha em Portugal, e logo se encontra em "adiantado estado de gravidez", nascendo então Gregório. Após algum tempo, Leão Vermelho viaja e deixa Cecília e Gregório sob os cuidados de Tubarão, seu antigo criado, pois desconfiava de algumas cartas que Cecília andava recebendo e instrui Tubarão a vigiá-la. O desfecho foi a descoberta de Pedro Ruivo, antigo noivo de Cecília e pai verdadeiro de Gregório. Ao tornar essa história conhecida de Tubarão e seu marido, Cecília enlouquece. Muda-se, então, o cenário. Gregório, personagem importante na história, passa a ser educado por Margarida, uma rica mulher que tem por Cecilia grande amizade. Ela se casa com o conde de São Francisco e vem para o Brasil. Gregório (após o nascimento da filha de Margarida) passa a viver com d. Florentina de Aguiar.

Outro grupo de personagens tem como foco Júlia de Guterrez, uma viúva enriquecida com a herança do marido e que passa a ser amante de Gregório, homem inconstante, que se apaixona por muitas mulheres. Assim, apaixona-se por Olímpia (antes de Júlia) e também por Clorinda, de quem fica noivo. A narrativa começa momentos antes do casamento de Gregório e Clorinda, o qual não ocorre, pois Gregório foi raptado pelo conde de S. Francisco: ele não poderia se casar com Clorinda porque ela era sua irmã por parte de pai. 
Paralelamente, ainda há a família do comendador Ferreira, um rico comerciante, casado pela segunda vez com Teresa, com uma filha do primeiro casamento, Olímpia. Ela era separada do marido, o caixa da casa Paulo Cordeiro. O comendador Portela, outro personagem importante, havia se tornado um rico comerciante no negócio de vinhos. Entretanto, antes disso trabalhara para o comendador Ferreira e tinha em Teresa (mulher de Ferreira) a sua amante. Assim, combina com ela uma forma de assassinar o marido envenenando-o, para que pudesse casar com Teresa e aproveitar-se da sua herança. No entanto, o comendador Ferreira descobre o plano e mantém as cartas e outros papéis que os denunciavam sob sua guarda.

Apesar de aparentemente desconexas, a história tem como ponto de encontro um crime ocorrido no armazém de rapé de Paulo Cordeiro, que envolve roubo e assassinato. Logo nas primeiras páginas, encontra-se o cadáver:

Era um defunto comprido, magro, com as barbas empastadas de sangue pelo lado inferior. Estava descalço e tinha o corpo nu, ligeiramente esverdeado. O assassino havia-lhe rasgado a garganta com uma faca e puxara o golpe até as regiões dérmicas do tórax. (AZEVEDO, s.d., p.14)

Após inúmeros caminhos que confundem o leitor em relação aos motivos do crime e ao criminoso, descobre-se, quase no final da narrativa, que Pedro Ruivo havia roubado o dinheiro. Descrito como um velhaco e gatuno, rouba uns papéis do comendador Ferreira que acusavam Portela de tentar assassiná-lo. Ao tentar chantageá-lo, passa a ser perseguido por Talha-certo, guarda-costas do comendador Portela, que, além de matar Pedro Ruivo, rouba o dinheiro que este havia roubado.

Apesar de aparentemente desconexas, portanto, os personagens vão se cruzando ao longo do livro em decorrência do crime, que é desvendado somente no final do romance e tem no julgamento de Talha-certo o último capítulo:

Seguiu-se então o mais estranho e enovelado processo de que se pode gabar a justiça brasileira. Nesse tempo não se falava n'outra coisa: o processo agitou por muitos dias a curiosidade do público e fechou todos os personagens deste romance no mesmo círculo de interesse. (AZEVEDO, s.d., p. 227)

Paralelamente às idas e vindas do enredo, o autor intercala um capítulo complementar a "Onde o autor põe o nariz de fora", denominado "Parênteses". ${ }^{10}$ O que se espelha nesses adendos que se introduzem em meio à narrativa é a explicação de um projeto que teria como pano de fundo o romance moderno, que deveria ser uma "cópia fiel da vida" (AZEVEDO, s.d., p.219). Para Aluísio Azevedo, o romance brasileiro praticamente inexistia. Assim, somente dois autores se salvariam: Alencar, com Guarani e Iracema, não escreveu romances, mas dois "magníficos poemas" de "concepções nimiamente poéticas" onde "tudo é imaginário, fantástico, artificial"; Memórias de um Sargento de Milícias, de Manuel Antonio de Almeida, ainda não foi mais do que uma tentativa, válida, mas que não teve grandes "alçadas". Portanto, Aluísio Azevedo, dirigia-se ao leitor pedindo desculpas por "encravar" no meio do romance essas considerações: "em matéria de romance brasileiro, está tudo entre nós por fazer e criar. Cada um deve ir aproveitando 
como puder a ocasião, para conduzir o leitor ao bom caminho e desviá-lo das traduções francesas" (AZEVEDO, s.d., p.221).

Aluísio Azevedo estava interessado em mudar o gosto do público, adaptá-lo a uma literatura diferenciada, que teria como princípio básico criar mais do que uma história realista e "retratar a vida". Para isso, deveria falar sobre tudo, não se isentando dos vícios nem das virtudes. Como a vida, o romance deveria trazer "cenas argamassadas", personagens que têm um pouco de "herói e um pouco de saltimbanco", exibir coisas e pessoas na sua hediondez, pois "nada há totalmente feio". Mais ainda, no caso brasileiro, não haveria como se espelhar nos romances franceses ou ingleses, já que a natureza e o meio são completamente distintos:

"Não! Quem quiser copiar a nossa natureza e retratar os sentimentos do brasileiro, há de
fatalmente verter no seu quadro todas as cores, lançar mão de todos os processos. Nada se
pode omitir; não se pode escolher esta ou aquela escola estabelecida no romance porque
nenhuma delas nos convém. Não há sistema criado que nos possa aproveitar." (AZEVEDO,
s.d., pp.219-20)

O escritor traz algo do hibridismo literário, como afirmava Mérian, introduzindo pequenas doses de naturalismo em meio à ficção folhetinesca. Ele apresenta um projeto que tem como fim a criação do romance nacional. Para isso, não havia a impossibilidade de formas estéticas conviverem pacificamente, entre elas o romance-folhetim de ação e movimento e o naturalismo. Em Mistério da Tijuca havia a tentativa de elaborar uma narrativa que atendesse a essas propostas. Para ele, o gênero deveria ser reconhecido pelo grande público e resulta desse fato a inserção de trechos analíticos e explicativos nesta edição de Mistério da Tijuca, a qual atingiria um público amplo, já que publicada em forma de folhetim e, logo após, em volume. ${ }^{11}$

Com efeito, ao longo de sua história, Aluísio Azevedo foi sucesso de público e teve uma produção invejável em termos de quantidade de romances. É patente a sua preocupação em atingir o "grosso público", ao qual dirigia explicações detalhadas que acompanhavam a ação do romance:

\footnotetext{
Mas, querido leitor, se te sentes aborrecido, se te cansam as nossas descrições mal desenhadas, se te enfastiam as nossas modestas considerações a respeito do histerismo de D. Olímpia, dos sobressaltos e da moléstia nervosa da mulher do comendador Ferreira, decide-te a nos prevenir dessa desgraça enquanto é tempo, fala-nos com franqueza em uma carta, em uma declaração de qualquer espécie, que nós tomaremos a heróica resolução de apressarmos o passo e quanto antes te lançaremos ao nariz o desfecho da obra.

Sabes, e se não sabes fica sabendo, que os fatos que aí deixamos, tão a míngua descritos, não são puramente inventados por nós, mas colhidos aqui e ali da vida real. Cada um dos tipos deste romance tem atrás de si um ou mais indivíduos, que encontramos na rua, no teatro, nas repartições públicas ou em alguma reunião de família.

Andamos como os trapeiros, de saco às costas a mariscar por aí nesse mistifório de paixões boas e más, de bons e maus impulsos, de intenções de toda a espécie, nessa mistela de virtudes heróicas e misérias degradantes, de cuja argamassa se forma a estranha coisa, que se chama - vida humana.

(...) Vês, por conseguinte, que seguimos o curso fatal de certas leis. Não é bastante dizer, é preciso dizer e explicar. (Folha Nova, 23 jan. 1883)
} 
Todas as passagens desses dois capítulos soam, a princípio, como um pedido de desculpas. Porém, entremeado a este longo jogo de palavras, o autor sugere uma possibilidade de leitura do romance: tal emaranhado de cenas e personagens estaria no "curso fatal de certas leis". A "estranha direção da obra" que se caracteriza por este labiríntico caminho tem, portanto, um motivo claro. O fio condutor de Mistério da Tijuca é um crime. Segundo Raimundo de Menezes, foi um caso verídico romanceado pelo escritor (MENEZES, 1957). Pode-se dizer que Alú́sio Azevedo dominava este tipo de procedimento que, como vimos, foi realizado em Casa de Pensão. ${ }^{12}$ Talvez não esteja na contestação da veracidade ou não da história a maior importância do argumento, mas em notar que o escritor utilizava temas populares e de sucesso para constituir alguns de seus romances. E não haveria assunto mais popular do que crimes (PORTO, 2003).

Através de um crime, o autor aproximava obras que, aparentemente, poderiam se distanciar, como Casa de Pensão e Mistério da Tüuca. Assim como ocorreria em Casa de Pensão, que deu destaque ao julgamento e consequente assassinato de Amâncio nos últimos capítulos, o último capítulo de Mistério da Tïuca não poderia ser diferente - a resolução do caso na justiça:

Foi dos depoimentos, das declarações anônimas, das mofinas e do que confessaram as pessoas enredadas nas tramas dessa pendência, que tiramos a porção de páginas mal alinhavadas, que aí ficam para nosso descrédito. (...) Agora pouco nos resta a acrescentar para terminarmos a obra. (AZEVEDO, s.d., p.227)

\section{Entre Mistérios da Tijuca e Casas de Pensão}

Em novembro de 1884, em uma carta “antipática e mal conformada”, Aluísio Azevedo recorria a Afonso Celso, implorando-lhe uma colocação em qualquer posto público, pois pretendia "continuar a sarroliscar os meus pobres romances, sem ser preciso fazê-los au jour le jour" (AZEVEDO, 1961, p.191). No final da carta, confessava ao deputado e amigo:

\footnotetext{
Ora, dessa forma, só fazendo como neste momento faço: vindo a ti e pedindo-te que, logo que te passe pelos olhos um desses cargos, lhe ponhas a mão em cima e me atires com ele, que eu o receberei com melhor vontade do que a de um náufrago ao receber uma tábua de salvação. Repito: seja lá o que for - tudo serve; contanto que eu não tenha de fabricar Mistérios da Tijuca e possa escrever Casas de Pensão.

Talvez te pareça feio e até ridículo o que acabo de fazer; não sei, mas, desnorteado como estou, sôfrego por acentuar esta maldita existência de boêmio que já se me vai tornando insuportável, agarro-me a ti, por julgar-te mais perto de mim e mais apto do que outro qualquer, para compreender a sinceridade e o desespero do que estou dizendo.” (AZEVEDO, 1961, p. 192)
}

Neste final de 1884, Aluísio Azevedo já era famoso como romancista, tornando-se patente o seu sucesso de público, tanto pelos comentários na imprensa, quanto pelo número de romances publicados em um curto espaço de tempo. Assim, entre 1882 e 1884, publicava quatro romances: Memórias de um Condenado na Gazetinha em 1882; Mistério da Tijuca na Folha Nova em 1882-3; Casa de Pensão, folhetim e livro entre 1883-4; Filomena Borges na Gareta de Notícias em 1883. 
Apesar do sucesso, torna-se significativo que, em meio a este turbilhão de narrativas, venha o "pedido de socorro", o qual se concretizaria para o autor através da ocupação de um posto público. O que mais se evidencia na carta é a insatisfação com o mercado das letras, no qual vinha se inserindo de maneira paulatina e intensa, exercendo a sua profissão (não tão bem remunerada e reconhecida) de homem que vive dos seus escritos: ele não queria mais "fabricar romances".

Naquele momento, tal mercado era pautado, em grande medida, pelas incursões na imprensa, principalmente no espaço destinado à publicação de romances, o rodapé. $O$ grande número de títulos de jornais publicados, inclusive alguns com pouca permanência no mercado - como foi o caso da Folha Nova - fazia com que se criasse um tipo de indústria de romances, que era impulsionada pela tradução de sucessos europeus (MEYER, 1996; MÉRIAN, 1988) e pela inserção de novelas nacionais. ${ }^{13}$

De forma geral, os autores não gostavam deste tipo de produção industrial e massificada de romances, como fica patente pela insatisfação de Aluísio Azevedo, ao comentar os erros tipográficos existentes em Memórias de um Condenado. O volume permitiria menores chances de erro, principalmente em relação à impressão e aos descuidos dos tipógrafos das folhas diárias que, em grande medida, interferiam na narrativa ao mudar palavras e fazer adaptações do texto manuscrito. ${ }^{14}$

Além disso, para o escritor, o trabalho de realizar um romance au jour le jour era penoso e exigia não somente a escrita cotidiana, mas adaptações que estimulassem a leitura diária. Assim, necessariamente, o romance-folhetim necessitava de uma relação entre escritor e leitor que fazia com que o primeiro compreendesse os anseios do segundo e, através da escrita cotidiana, o fosse suprindo pela narrativa que se delineava nas ações dos personagens e no estilo, impulsionado, evidentemente, pelo corte diário.

Essas características podem ser captadas através de uma compreensão dos romances a partir das formas de publicação e de uma análise que favoreça não tanto as características que poderiam relacioná-los a movimentos literários mais amplos, mas que explicite situações específicas daquela narrativa.

Portanto, comparar Mistério da Tijuca a Casa de Pensão permite perceber que, apesar de Aluísio Azevedo expressar opiniões distintas em relação aos romances - um foi "fabricado" e o outro "escrito" - na prática estas diferenças não foram tão enfáticas, podendo-se notar uma tensão permanente entre a intenção do autor e a efetivação das obras.

O que mais chama atenção e deve ser notado é a importância do crime. Tanto Mistério da Tijuca quanto Casa de Pensão desenvolvem a narrativa a partir da elucidação de um crime. Em Mistério da Tijuca o assassinato de Pedro Ruivo é exposto ao leitor já nas primeiras páginas, mas a longa narrativa que, em muitos momentos, quase deixa escapar este evento pelas exposições e descrições de personagens e suas relações, volta sorrateiramente a arrebatar a curiosidade do leitor.

Casa de Pensão, ao contrário de Mistério da Tijuca, indica o caminho do crime ao longo da narrativa, o qual só ocorre nas últimas páginas. Apesar dessa diferença, é inconcebível uma compreensão deste romance sem se remeter às referências explícitas ao caso verídico, o "Affaire Capistrano". Modificando certas sutilezas do caso, Aluísio Azevedo fornece ao leitor o caminho inevitável do crime de assassinato de Amâncio. 
Seria impossível imaginar que Aluísio Azevedo escreveria duas obras tão distintas em tão curto espaço de tempo. Porém, a única maneira de aproximá-las é considerar que ambas foram feitas para o grande público e em um mesmo contexto de produção. Desta forma, a confissão de Aluísio Azevedo a Afonso Celso no final de 1884 passa a ser compreensível somente se considerarmos que ela se formou ao longo de dois anos de intensos elogios à Casa de Pensão, além de ressaltar a tensão permanente que assolava o escritor ao realizar as suas obras naquele momento. Afinal, quem deveria ser agraciado: a crítica ou o leitor?

\section{Bibliografia}

AZEVEDO, Aluísio. Mistério da Tijuca. Rio de Janeiro: Tipografia da Folha Nova, s.d. . Casa de pensão. São Paulo: Livraria Martins, 1957. O touro negro. São Paulo: Livraria Martins, 1961.

A.F.R.J. O assassinato de João Capistrano da Cunha. Rio de Janeiro: Tipografia de Juvêncio Thomaz de Aquino. 1876.

ARARIPE JUNIOR, Tristão de Alencar. Obra crítica de Araripe Junior. Volume II (1888-1894). Rio de Janeiro: Ministério da Educação e Cultura, Casa de Rui Barbosa, 1960.

CAUFIELD, Sueann. Em defesa da honra. Moralidade, modernidade e nação no Rio de Janeiro (1918-1940). Campinas: Editora da Unicamp, Centro de Pesquisa em História Social da Cultura, 2000

ESTEVES, Marta de Abreu. Meninas perdidas. Os populares e o cotidiano do amor no Rio de Janeiro da Belle Époque. Rio de Janeiro: Paz e Terra, 1989.

GRANDO, Marizete Liamar. Processo de produção ficcional do romance Casa de Pensão. Dissertação de mestrado. São Paulo: Usp, 2004.

MARQUES JÚNIOR, Milton. Da ilha de São Luis aos refolhos de Botafogo. João Pessoa: Editora Universitária/ UFPB, 2000.

MARTÍNEZ-ALIER, Verena. "Elopement and seduction in nineteenth-century Cuba”. In Past and Present, 55 (1972)

MENEZES, Raimundo de. Aluísio Azevedo. Uma vida de romance. São Paulo: Livraria Martins Editora, 1957

MÉRIAN, Jean-Yves. Aluísio Azevedo. Vida e obra (1857-1913). Rio de Janeiro: Espaço e Tempo Banco Sudameris; Brasília: INL, 1988.

MEYER, Marlyse. Folhetim. Uma história. São Paulo: Companhia das Letras, 1996.

PORTO, Ana Gomes. Crime em letra de forma. Sangue, gatunagem e um estranho esqueleto na imprensa do prelúdio republicano. Dissertação de mestrado. Campinas: Unicamp, 2003.

SILVA, Ana Cláudia Suriani. Quincas Borba: folhetim e livro. Thesis submitted in partial of the requirements for the degree of DPhil in Portuguese in the Faculty of Medieval and Modern Languages. Oxford: University of Oxford, 2007.

WEEKS, Jeffrey. Sex, politics and society: the regulation of sexuality since 1800. Londres: Longman, 1989

\section{Notas}

\footnotetext{
${ }^{1}$ Este artigo faz parte de uma pesquisa de doutorado que teve o financiamento da CAPES e da FAPESP.

${ }^{2}$ Segundo Sá Pinho: "Deve ser distribuído brevemente o primeiro fascículo da Casa de Pensão, último romance de Aluísio Azevedo. Aluísio Azevedo tem empregado o máximo esmero na elaboração desta obra, e a Casa de Pensão vai ser talvez o primeiro estudo sério que se tenha feito entre nós, na esfera do romance. Esta qualidade, por um lado, e por outro lado, a maneira cômoda por que se pretende efetuar a venda do livro, prenunciam um bom êxito...- Esse sucesso que saia!" (O Mequetrefe, 30 mai. 1883). Ainda segundo K. Loiro: "Acha-se já distribuído o primeiro fascículo da Casa de Pensão, romance cujo aparecimento fomos dos primeiros a anunciar
} 
pela imprensa. Para não dar ouvidos ao errôneo paradoxo de que pelo dedo se conhece o gigante, não antecipamos nenhum juízo sobre esta obra, baseados apenas em algumas páginas. Aguardamos ocasião mais oportuna. Por enquanto, para entreter os nossos honrados ócios de crítico, limitamo-nos a folheá-la, de pena ao léu." $(O$ Mequetrefe, 10 jun. 1883).

${ }^{3}$ Ver prefácio da $8^{a}$ edição. Trata-se da edição de F. Briguiet \& Cia, após aquelas impressas pela Livraria Garnier. $\left(4^{\mathrm{a}}, 5^{\mathrm{a}}, 6^{\mathrm{a}}, 7^{\mathrm{a}}\right)$.

${ }^{4}$ Tudo indica que o romance seguiu a publicação sob a forma de fascículos. Porém, é difícil qualquer especulação em torno deste fato, como faz Marizete Liamar Grando, que sugere que o "sucesso que [o romance] atingiu no formato de romance-seriado induziu o autor à interrupção da sequência de sua publicação, obrigando seu público a aguardar aproximadamente um ano para ler o romance em seu todo" GRANDO, 2004, pp.16-7. Filomena Borges foi publicado entre 10 de novembro de 1883 e 13 de janeiro de 1884, o que indicaria a possibilidade de que os fascículos de Casa de Pensão circularam antes, pois o início do romance já havia sido publicado sob a forma de folhetim.

${ }^{5}$ As notícias do crime foram extensas na Gazeta de Notícias. O Jornal do Commercio também comenta o ocorrido. Concentram-se entre meados de novembro de 1876 e janeiro de 1877.

${ }^{6}$ Ver "A advocacia, Alexandre Pereira e as famílias brasileiras", em Gazeta de Notícias, 27 nov. 1876; Debates entre o autor de "A Semana". Folhetim do Jornal do Commercio e $A$ Lanterna, periódico quinzenal, especialmente dias 25 e 26 de novembro de 1876; Gazeta de Notícias, 27 nov. 1876; O assassinato de João Capistrano da Cunba. Escrito pela pena imparcial do estudante A.F. R.J., Tipografia de Juvêncio Thomaz de Aquino, 1876. Folhetos a 200 réis. 7 “(... é verdade que nem sempre no momento da sedução há o propósito do abandono, e a sedução não tem por consequência inevitável a prostituição; mas admitindo mesmo que as condições figuradas de temperamento, de intensidade de paixões, prevaleçam somente para desculpar a mulher que se deixou seduzir e não sirvam para atenuar o erro do homem que seduziu: supondo mesmo que todas as mulheres perdidas tenham sucumbido à paixão ou à miséria, o que não é verdade (...)". Gazeta de Notícias, 26 nov. 1876. A bibliografia sobre a defesa de honra ou o crime de sedução neste período e nos anos iniciais do século XX é extensa.

${ }^{8}$ Trata-se da primeira edição em livro. Possivelmente a data de edição foi 1882 ou 1883. Reparo que, ao transformar Mistério da Tijuca em Girândola de Amores, houve mudanças significativas em relação à estrutura do romance.

${ }^{9}$ A prática poporcionava aos leitores a possibilidade de reler o romance sem os cortes cotidianos. Certamente a leitura da história no volume fornecia outra perspectiva de leitura. Sobre o assunto ver SILVA, 2007.

${ }^{10}$ Sobre o assunto, ver as conclusões de MARQUES JÚNIOR, 2000.

${ }^{11}$ SILVA, 2007, tece comentários interessantes em relação à multiplicação de leitores da publicação de romances no rodapé das folhas e posteriormente em volume, especialmente no capítulo 1: "Romances em folhetim e livro".

${ }^{12}$ Assim como Aluísio Azevedo romanceava crimes, deve-se reparar no significado que teria a proposta feita por Valentim Magalhães nas páginas do jornal O Estado de São Paulo, alguns anos depois, em 1890. Trata-se de um comentário sobre as reportagens de um crime que havia ocorrido no Rio de Janeiro: "O assassinato de Mme. Asty". Em vista da falta de notícias que aproveitassem adequadamente o caso, o escritor propõe que se eleja Aluísio Azevedo e Raul Pompéia como ideais para dar uma feição adequada às notícias na imprensa. Para ele, o crime deveria ser "tratado à moderna" para "entreter a insaciável curiosidade do público" e não existiria ninguém melhor que Aluísio Azevedo, "um romancista de pulso", pois "tudo haveria de examinar de perto, fazendo uma reportagem inigualável". Raul Pompéia se encarregaria de "aprofundar o estranho caso de psicologia criminal". Magalhães, Valentim. "Semana Fluminense". O Estado de São Paulo, 30 mai. 1890.

${ }^{13}$ Dois romances poderiam ser publicados ao mesmo tempo, variando o dia de publicação. Além da publicação de romances, este espaço era destinado aos comentários sobre a semana ou algum assunto em pauta no momento.

14 “(...) os erros tipográficos são tantos e tão constantes, que constituem uma verdadeira calamidade. Ainda no último folhetim, eu escrevi - belos brilhantes, e os tipógrafos disseram - velhos brilhantes; em outro lugar falo de pedras limpas, e eles emendaram para límpidas. Isto sem querer citar as repetidas transposições que alteram completamente o sentido do que está escrito; as palavras incompletas, os saltos e mil outros inimigos do estilo e da boa lógica gramatical" (AZEVEDO, 1961, p.52). Ao sair a primeira edição em volume pela Tipografia do Liberal Mineiro em 1886, o autor não se diz satisfeito com a revisão e acrescenta um "adendo de insatisfação" ao texto. 
